ISSN: $1412-1212$

\title{
ThE 내inning ER
}

Accounting, Business, Management, and Information System

Volume 2, Nomor 2, September 2001

\begin{tabular}{|c|c|}
\hline \multicolumn{2}{|c|}{ Subbiro Publikasi Ilmiah bidang Ekonomi Universitas Bina Nusantara } \\
\hline Pelindung & $\begin{array}{l}\text { Ir. Th. Widia Soerjaningsih, M.M. } \\
\text { Once Kurniawan, S.Kom., M.M. } \\
\text { H. Mohammad Subekti, B.E., M.Sc. }\end{array}$ \\
\hline Redaktur Utama & Dr. Ir. Haryono Soeparno, M.Sc. \\
\hline Dewan Redaksi & $\begin{array}{l}\text { E.A. Kuncoro, S.E., M.M. } \\
\text { Ir. Harjanto Prabowo, M.M. } \\
\text { Retno Sri Handini, S.E., M.Phil. }\end{array}$ \\
\hline Mitra Bestari & $\begin{array}{l}\text { Dr. Hekinus Manao, M.Acc., C.G.F.M. } \\
\text { (Universitas Indonesia) } \\
\text { Dr. Sudarwan, M.B.A., Q.I.A. } \\
\text { (Universitas Trisakti) } \\
\text { Dr. Ir. Roy Sembel, M.B.A. } \\
\text { (Program Pascasarjana Universitas Bina Nusantara) } \\
\text { Edi Timbul Hardiyanto, S.E., Ak., M.Sc., M.B.A., B.A.P } \\
\text { (Institut Pendidikan Internal Auditor Indonesia) }\end{array}$ \\
\hline Editor & Dra. Endang Ernawati, M.Lib. \\
\hline Sekretariat & $\begin{array}{l}\text { Yanti, S.Kom., M.M. } \\
\text { Triwiyana }\end{array}$ \\
\hline Alamat Sekretariat & $\begin{array}{l}\text { Subbiro Publikasi Ilmiah bidang Ekonomi, } \\
\text { Biro Penelitian dan Publikasi, Universitas Bina Nusantara } \\
\text { Kampus Syahdan, Jl. K.H. Syahdan No. 9, } \\
\text { Kemanggisan - Palmerah, } \\
\text { Jakarta Barat } 11480 \\
\text { Telp. (021) 5345830, } 5350660 \text { ext. } 2206 \text { Fax. (021) } 5300244 \\
\text { e-mail: mgt2000@binus.ac.id }\end{array}$ \\
\hline ISSN & $1412-1212$ \\
\hline
\end{tabular}


ISSN: $1412-1212$

\section{ThE UHingment}

Accounting, Business, Management, and Information System

Volume 2, Nomor 2, September 2001

\section{DAFTAR ISI}

Kata Pengantar.

\section{Yulius}

Heavy Reliance on the Indirect Financing as Sources of Funds for Business Firms

in Japan: As a Comparison for Indonesian Financial Crisis.

\section{Teguh Sriwidadi}

Manajemen Mutu Terpadu

(Total Quality Management).....

\section{Budiman Notoatmojo}

Peranan Gender dalam Usaha Tani di Kawasan Indonesia Bagian Timur

(Roles of Gender in Farmers Business in the Eastern Indonesia).

\section{Haryadi Sarjono}

Model Pengukuran produktivitas Berdasarkan pendekatan Rasio Output per Input (A Model of Productivity Measurement Based on Output per Input Approach)

\section{Suryanto}

Manajemen Lintas Budaya

(Crosscultural Management)

Titik Indrawati

Merger Bank Bermasalah di Indonesia

(Merger of Troubled Bank in Indonesia)....

\section{Fauzi Solihin}

Mengenal Bank "Syariah” Lembaga Keuangan untuk Umum

(Introducing "Syariah" Bank as a Public Financial Institution)..... 


\section{KATA PENGANTAR}

Journal The WINnERS untuk penerbitan Vol. 2 No. 2, September 2001 berisi tujuh artikel yang membahas masalah heavy reliance on the indirect financing as sources of funds for business firms in Japan: as a comparison for Indonesian financial crisis, manajemen mutu terpadu, peranan gender dalam usaha tani di kawasan Indonesia bagian timur, model pengukuran produktivitas berdasarkan pendekatan rasio output per input, manajemen lintas budaya, merger bank bermasalah di Indonesia, dan mengenal bank "Syariah" lembaga keuangan untuk umum.

Journal The WINNERS ini merupakan hasil kerja penulis, tim redaksi, dan partisipasi segenap civitas akademika yang menekuni bidang ekonomi. Mudah-mudahan jurnal ini bermanfaat bagi pembaca.

Jakarta, September 2001

Redaktur Utama

Dr. Ir. Haryono Soeparno, M.Sc. 


\section{UCAPAN TERIMA KASIH}

Ucapan terima kasih dan penghargaan diberikan kepada para pakar/ahli yang telah diundang sebagai penelaah artikel pada Journal The WINNERS dalam Volume 2 tahun 2001. Berikut ini daftar nama pakar/ahli yang berpartisipasi.

1. Dr. Hekinus Manao, M.Acc., C.G.F.M.

(Universitas Indonesia)

2. Dr. Sudarwan, M.B.A., Q.I.A.

(Universitas Trisakti)

3. Dr. Ir. Roy Sembel, M.B.A.

(Program Pascasarjana Universitas Bina Nusantara)

4. Edi Timbul Hardiyanto, S.E., Ak., M.Sc., M.B.A., B.A.P

(Institut Pendidikan Internal Auditor Indonesia) 